\title{
Platelet Membrane and Calcium Control Abnormalities in Essential Hypertension
}

\author{
F. R. Bühler and T. J. Resink
}

The mechanisms whereby intracellular calcium concentration is controlled are briefly reviewed. With the current knowledge of both calcium homeostasis and the function and properties of cellular $\mathrm{Ca}^{2+}$-target proteins / signal transduction systems, a dysfunction of cellular calcium metabolism is considered in relation to the pathogenesis of hypertension. Although the enhanced peripheral vascular resistance characteristic of hypertension is ultimately a function of $\mathrm{Ca}^{2+}$ availability for smooth muscle cell contraction, the platelet possesses many parallel biochemical and physiologic properties.
Therefore, we have utilized the platelet as the cell model for investigating the role of $\mathrm{Ca}^{2+}$ in hypertension disorders. An overview of $\mathrm{Ca}^{2+}$-linked platelet processes altered in essential hypertension is presented, and an attempt is made to integrate these multiple aberrations in a fundamental membrane lesion. Am J Hypertens $1: 42-46,1988$

KEYWORDS: essential hypertension, calcium control, platelets, phosphoinositides, cyclic nucleotides.

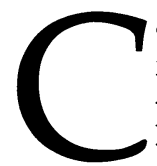
alcium is a fundamental regulator of cellular function. An understanding of the general principles of cellular $\mathrm{Ca}^{2+}$ regulation is crucial to the pathophysiology of hypertension and its effective treatment, because the heart, adrenal glomerulosa, neural synapses, juxtaglomerular apparatus, platelets, and smooth muscle cells use $\mathrm{Ca}^{2+}$ as a positive intracellular messenger.

Intracellular calcium concentrations $\left(\left[\mathrm{Ca}^{2+}\right]_{\mathrm{i}}\right)$ are regulated by a complex array of transport mechanisms at various membrane and intracellular locations. The entry of $\mathrm{Ca}^{2+}$ from the extracellular space is mediated by voltage-sensitive $\mathrm{Ca}^{2+}$ channels and other putative mechanisms including release of $\mathrm{Ca}^{2+}$ bound to membrane surfaces, entry through receptor-mediated channels, or nondefined passive leak across the membrane. $\mathrm{Ca}^{2+}$ is also released from internal endoplasmic reticulum and

From the Departments of Research and Medicine, University Hospital, Basel, Switzerland

This work was supported by grants from the Swiss National Fund (No. 3.824.083).

Address correspondence and reprint requests to Prof FR Bühler, Division of Cardiology, University Hospital, CH-4031 Basel, Switzerland. from mitochondria. In resting cells, $\left[\mathrm{Ca}^{2+}\right]_{\mathrm{i}}$ is maintained at $10^{-7} \mathrm{M}$, that is, considerably lower than millimolar extracellular free $\mathrm{Ca}^{2+}$. In stimulated cells, $\left[\mathrm{Ca}^{2+}\right]_{\mathrm{i}}$ does not generally exceed $10^{-5} \mathrm{M}$. Therefore, under both conditions, internal calcium levels are necessarily maintained by the action of active transport mechanisms that remove $\mathrm{Ca}^{2+}$ from the cytosol, including the plasma membrane ATP-dependent $\mathrm{Ca}^{2+}$ pump, the plasma membrane $\mathrm{Na}^{+}-\mathrm{Ca}^{2+}$ exchanger, the endoplasmic reticulum ATP-dependent $\mathrm{Ca}^{2+}$ pump, and the mitochondria $\mathrm{Ca}^{2+}$ pump. The net result of the operation of all these $\mathrm{Ca}^{2+}$-translocating mechanisms is the imbalance of $\mathrm{Ca}^{2+}$ concentrations within the cells, which are therefore primed for $\mathrm{Ca}^{2+}$-signaling events to permit a rapid and large increase incytosolic $\mathrm{Ca}^{2+} .{ }^{1-3}$

\section{ESSENTIAL HYPERTENSION, PLATELETS, AND CALCIUM}

In the pathophysiology of essential hypertension (EHT), several factors have been proposed, including enhanced sympathetic nervous system activity, reduced renin-angiotensin-aldosterone axis endocrine control, dietary salt, and genetic factor(s). Direct clinical corollaries for an integrative contributory role for $\mathrm{Ca}^{2+}$ in the pathophysiology of EHT are that patients with EHT exhibit 
excess calcium-influx-dependent vasoconstriction and that blood pressure in these patients is normalized following therapy with calcium antagonists. ${ }^{4-6} \mathrm{~A}$ key characteristic of EHT is elevated peripheral vascular resistance, which is ultimately mediated by enhanced vascular contractility. An altered state of vascular reactivity can result from alterations in either cellular calcium metabolism or the sensitivity of response elements to the actions of $\mathrm{Ca}^{2+} .^{7-10}$ Investigations in search of support for the hypothesis that perturbation of calcium metabolism is a fundamental lesion in EHT have been carried out on a wide variety of tissue and cell types including myocardium, smooth muscle, erythrocytes, adipocytes, hepatocytes, synaptosomes, and platelets in both human and animal models of hypertension. ${ }^{7-10}$

A specific role for platelets in the pathophysiology of hypertension should be considered, because these cells are mediators of thrombotic complications, vectors for vascular tone, and promoters of atherosclerosis. There are many similarities between platelets and smooth muscle cells. Both platelets and smooth muscle cells have an adenylate cyclase system that can be activated by adrenaline via $\alpha-2$ adrenoceptors and inhibited by prostaglandins with attendant changes in calcium. ${ }^{11}$ Calcium can be selectively stimulated via angiotensin II receptors, ${ }^{12}$ and calcium entry can be blocked by slow calcium channel inhibitors. ${ }^{13}$ There are similar calciumdependent contractile systems and similar pools for regulation of intracellular calcium (the dense tubular system in platelets and the sarcoplasmic reticulum in smooth muscle cells). ${ }^{1,2}$ There are comparable calciumdependent physiologic functions: shape change, aggregation and secretion in platelets, and contraction in smooth muscle cells. Hormone-receptor activation leads to parallel alterations in the clinical setting of EHT: increased sensitivity, shape change and aggregation of platelets, and increased vascular resistance of resistance vessels. These corollaries, together with easy clinical accessibility and preparative cellular homogeneity of platelets, focused our investigations on the human platelet as a model reflecting events occurring in smooth muscle cells.

It is the purpose of this paper to present a summary of present findings with respect to cellular $\mathrm{Ca}^{2+}$ handling in platelets from patients with EHT in search of support for the hypothesis ${ }^{7-10}$ that a generalized membrane defect is the common denominator underlying multiple $\mathrm{Ca}^{2+}$-associated abnormalities in hypertension. Our own specific observations are summarized in Table 1.

\section{CYTOSOLIC FREE CALCIUM CONCENTRATIONS}

Intracellular calcium content has been demonstrated to be elevated in platelets, erythrocytes, and lymphocytes from patients with EHT. ${ }^{7-10,14-16}$ A correlation between platelet $\left[\mathrm{Ca}^{2+}\right]_{i}$ and blood pressure has also been estab-
TABLE 1. PLATELET Ca ${ }^{2+}$-LINKED ABNORMALITIES IN ESSENTIAL HYPERTENSION

\begin{tabular}{|c|c|c|}
\hline System & $\begin{array}{c}\text { Directional } \\
\text { Alteration }\end{array}$ & Consequence \\
\hline $\begin{array}{l}\text { Cytosolic free } \\
\text { calcium }\end{array}$ & Increased $^{11,14,17}$ & $\begin{array}{l}\text { Cell activation } \\
\text { promoted }\end{array}$ \\
\hline $\begin{array}{l}\text { Membrane poten- } \\
\text { tial }\end{array}$ & Decreased $^{21}$ & $\begin{array}{l}\mathrm{Ca}^{2+} \text { influx } \\
\text { increased }\end{array}$ \\
\hline $\begin{array}{l}\left(\mathrm{Ca}^{2+} \text {-calmodu- }\right. \\
\text { lin)-dependent } \\
\text { ATPase }\end{array}$ & $\begin{array}{l}\text { Capacity in- } \\
\text { creased but } \\
\text { activation } \\
\text { potential de- } \\
\text { creased }^{24}\end{array}$ & $\begin{array}{l}\text { Compensatory } \\
\text { but inefficient } \\
\text { stimulated } \mathrm{Ca}^{2+} \\
\text { extrusion }\end{array}$ \\
\hline $\begin{array}{l}\text { Hormone } \\
\text { (receptor) } \\
\text { sensitivity }\end{array}$ & Increased ${ }^{43}$ & $\begin{array}{l}\text { Potentiation of } \\
\text { stimulation }\end{array}$ \\
\hline $\begin{array}{l}\text { Phosphoinositide } \\
\text { metabolism }\end{array}$ & $\begin{array}{l}\text { Phosphoinositide } \\
\text { compositional } \\
\text { equilibrium } \\
\text { shifted toward } \\
\text { polyphos- } \\
\text { phoinositide } \\
\text { formation }^{37}\end{array}$ & $\begin{array}{l}\text { Potential for } \\
\text { internal } \mathrm{Ca}^{2+} \\
\text { release } \\
\text { increased; } \\
\text { modification of } \\
\text { membrane- } \\
\text { associated pro- } \\
\text { cesses }\end{array}$ \\
\hline Adenylate cyclase & $\begin{array}{l}\text { Activity ratio } \\
\text { (stimulated/ } \\
\text { basal) increased }\end{array}$ & Compensatory \\
\hline
\end{tabular}

A brief summary of our findings with respect to EHT and disorders of platelet systems that involve $\mathrm{Ca}^{2+}$. The directional nature of alterations is indicated, and other than proposed compensatory mechanisms, all modifications are considered to facilitate platelet shape change, aggregation, and secretion. Similar abnormalities may contribute to enhanced smooth muscle contraction in EHT.

lished. ${ }^{14}$ Normalization of platelet $\left[\mathrm{Ca}^{2+}\right]_{\mathrm{i}}$ occurs following antihypertensive therapy. ${ }^{17}$ Whatever the underlying mechanism, it is not entirely corrected by antihypertensive therapy, because platelets from treated EHT patients still exhibit an amplified, stimulated $\left[\mathrm{Ca}^{2+}\right]_{\mathrm{i}}$ response relative to control subjects. ${ }^{17}$ These data imply an intrinsic cellular defect and possibly disturbed mechanisms, including membrane $\mathrm{Ca}^{2+}$ binding, $\mathrm{Ca}^{2+}$ influx, hormone-receptor transduction coupling, univalent cation transport, and $\mathrm{Ca}^{2+}$ efflux/sequestration. ${ }^{7-10}$

\section{MEMBRANE $\mathrm{Ca}^{2+}$ BINDING AND $\mathrm{Ca}^{2+}$ INFLUX}

Calcium binds to various components of the cell membrane, including anionic phospholipids and proteins. Altered calcium handling is suggested by decreased $\mathrm{Ca}^{2+}$ binding to the inner and outer surface of plasma membranes of erythrocytes, adipocytes, and hepatocytes, ${ }^{7-10}$ perhaps due to a reduction in the number of $\mathrm{Ca}^{2+}$-binding sites (as opposed to an affinity alteration). ${ }^{18}$ Defective calcium binding has been proposed to favor depolarization with consequent activation of potential operated calcium channels. ${ }^{8}$ While studies of 
the function of potential dependent $\mathrm{Ca}^{2+}$ channels in hypertension are scarce, available data for synaptosomes and platelets of $\mathrm{SHR}^{19,20}$ and platelets of $\mathrm{EHT}^{21}$ indicate partial depolarization of plasma membranes. Such an abnormality could give rise to an increased basal $\mathrm{Ca}^{2+}$ influx and hence increased $\left[\mathrm{Ca}^{2+}\right]_{\mathrm{i}}$.

\section{PROTEIN $\mathrm{Ca}^{2+}$ BINDING AND $\mathrm{Ca}^{2+}$ EFFLUX}

Cytoplasmic divalent cation-binding substances have also been considered in the pathogenesis of hypertension, ${ }^{7-10}$ but most of them (ie, glycerophosphates, nucleotides, and inorganic phosphates) are characterized by $K_{D}$ values that are two to three orders of magnitude larger than the range of possible changes in $\left[\mathrm{Ca}^{2+}\right]_{\mathrm{i}}$. Rather, focus has been on the highly selective $\mathrm{Ca}^{2+}$-binding proteins $\left(\mathrm{K}_{\mathrm{D}} 10^{-6}\right.$ to $\left.10^{-8} \mathrm{M}\right)$ such as calmodulin, which plays a central role in the $\mathrm{Ca}^{2+}$-dependent regulation of eukaryotic cells. ${ }^{22}$ In EHT, a modification of interaction between calmodulin and its target proteins has been proposed. ${ }^{7,10}$ Of the many target proteins, the plasma membrane $\mathrm{Ca}^{2+}$-ATPase is of major interest because of its critical role in maintaining $\mathrm{Ca}^{2+}$ homeostasis via the promotion of $\mathrm{Ca}^{2+}$ efflux. ${ }^{23}$ The findings with respect to this efflux system in hypertension are somewhat varied, with reports of increased, decreased, or unaltered activities. ${ }^{724-28}$ The regulation of $\mathrm{Ca}^{2+}$-ATPase, however, is complex, and in addition to $\mathrm{Ca}^{2+}$ and calmodulin other factors such as membrane hydrophobicity, acidic phospholipids, polyphosphoinositides, and proteolysis can modulate $\mathrm{Ca}^{2+}$ efflux activity. ${ }^{7-23}$

\section{PHOSPHOINOSITIDE METABOLISM}

Phosphoinositides may influence not only the plasma membrane but also internal membranes. Stimulated $\mathrm{Ca}^{2+}$ release from large stores in the endoplasmic reticulum is believed to be mediated by inositol $1,4,5$ trisphosphate, a product of hormone-activated phosphoinositide hydrolysis. ${ }^{30-34}$ Phosphoinositide metabolism is also implicated in the regulation of $\mathrm{Ca}^{2+}$ influx/efflux via the plasma membrane, membrane fluidity, membrane $\mathrm{Ca}^{2+}$ binding, and membrane $\mathrm{Ca}^{2+}$-ATPase and adenylate cyclase activities. ${ }^{29-33} \alpha_{1}$-adrenoceptors are directly coupled to phosphoinositide turnover (as are vasopressin and angiotensin II receptors), while $\alpha_{2}$ adrenoceptors are coupled to adenylate cyclase inhibition. ${ }^{34}$ Postreceptor stimulus-coupling cascades are not mutually exclusive, and pivotal integrated cellular control is mediated via a triangle of second messengers, namely $\mathrm{Ca}^{2+}$, cyclic AMP, and inositol 1,4,5 trisphosphate. Available evidence from studies on erythrocytes and platelets in animal and human models of hypertension point to the involvement of the phosphoinositides ${ }^{35-39}$ Similar investigations of smooth muscle cells, which exhibit many more blood pressure regulating hormone receptors than the platelets or erythrocytes, are necessary. The relationship between alterations in phosphoinositide metabolism and membrane-associated biochemical processes requires definition in order to assign causative or consequential roles in the pathogenesis of hypertension.

\section{$\mathrm{Ca}^{2+}$ AND CYCLIC NUCLEOTIDES}

Cyclic nucleotides are involved in the regulation of heart contractility, vascular smooth muscle tone, release and action of catecholamines, and control of renin secretion. ${ }^{40}$ Most functions are regulated (either synergistically or antagonistically) by $\mathrm{Ca}^{2+}$ and cyclic AMP. ${ }^{40}$ Accordingly, the finding of several anomalies in cyclic nucleotide metabolism in SHR and EHT is not surprising, ${ }^{41-43}$ although many of the findings are qualitatively discrepant.

Of particular interest is adenylate cyclase, a membrane-bound enzyme that regulates the synthesis of cyclic AMP via stimulatory $\left(\mathrm{N}_{\mathrm{s}}\right)$ or inhibitory $\left(\mathrm{N}_{\mathrm{i}}\right)$ guanine nucleotide-binding proteins. ${ }^{44} \mathrm{~N}_{\mathrm{i}}$ is regulated by protein kinase $\mathrm{C}$, a $\mathrm{Ca}^{2+}$-activated, diacylglycerol-modulated enzyme. ${ }^{29,45}$ Adenylate cyclase can also be activated by calmodulin and low concentrations of $\mathrm{Ca}^{2+}$ $(>0.8 \mu \mathrm{M})$ in many cells, including platelets and smooth muscle; higher $\mathrm{Ca}^{2+}$ concentrations are inhibitory. ${ }^{46,47}$ Cyclic AMP in turn may influence $\left[\mathrm{Ca}^{2+}\right]_{\mathrm{i}}$ by promoting $\mathrm{Ca}^{2+}$ efflux/sequestration. ${ }^{40,48}$ Thus, derangements in either phosphoinositide, $\mathrm{Ca}^{2+}$, and/or cyclic AMP metabolism may be expected to have profound and manifold effects on cell function.

\section{CONCLUDING REMARKS}

In the past few years our studies on alterations in calcium and cyclic nucleotide metabolism in EHT have been confined to platelets. The complexities of both cellular $\mathrm{Ca}^{2+}$ control and coordinated second-messenger regulation of cellular function make it difficult to assign causative or consequential roles to deranged platelet $\mathrm{Ca}^{2+}$-linked processes in the pathophysiology of essential hypertension. Nevertheless, our studies support an underlying membrane pathology as being causative because all the derangements described abovepotential, $\mathrm{Ca}^{2+}$-ATPase, hormone responsiveness, adenylate cyclase, and event cytosolic $\left[\mathrm{Ca}^{2+}\right]$ concentrations - are membrane-associated systems. Modifications of phosphoinositide metabolism may be a key factor accounting for the multifaceted membrane abnormalities associated with EHT. The studies need to be extended to the smooth muscle cell itself to determine whether similar abnormalities are present in the vasculature and relevant to elevated peripheral vascular resistance in hypertension.

\section{ACKNOWLEDGMENT}

Amanda de Sola Pinto is thanked for her secretarial assistance. 


\section{REFERENCES}

1. Gill DL: Horizons Biochem Biophys 1982;6:199-236.

2. Rasmussen H, Goodmann DBP: Physiol Rev 1979; 57:421-509.

3. Exton JH: Adv Cycl Nucl Prot Phosph Res 1986;20:214262.

4. Bühler FR, Hulthén UL: Calcium channel blockers: A pathophysiologically based antihypertensive treatment concept for the future? Eur J Clin Invest 1982;12:1-3.

5. Bühler FR, Hulthén UL, Kiowski W, et al: The place of the calcium antagonist verapamil in antihypertensive therapy. J Cardiovasc Pharmacol 1982; 4:S350-S357.

6. Müller FB, Bolli $\mathrm{P}$, Linder L, et al: Calcium antagonists and the second drug for antihypertensive therapy. Am J Med 1986;81:25-34.

7. Postnov $\mathrm{YV}$, Orlov $\mathrm{SN}$ : Ion transport across plasma membrane in primary hypertension. Physiol Rev 1985;65:904.

8. Robinson BF: Altered calcium handling as a cause of primary hypertension. J Hypertension 1984;2:453.

9. Friedman SM: Cellular ionic perturbations in hypertension. J Hypertension 1983;1:109.

10. Postnov YV, Orlov SN: Cell membrane alteration as a source of primary hypertension. J Hypertension 1984;2:1.

11. Erne $P$, Bühler FR, Affolter $\mathrm{H}$, et al: Excitatory and inhibitory modulation of intracellular free calcium in human platelets by hormones and drugs. Eur J Pharmacol 1983;91:331.

12. Moore T, Williams GH: Angiotensin II receptors on human platelets. Circ Res 1982;51:314.

13. Resink TJ, Erne P, Bühler FR: The influence of CGP 28392, a 1,4-dihydropyridine on human platelet calcium and cyclic AMP metabolism. Eur J Pharmacol 1985;113:383.

14. Erne $P$, Bolli $P$, Bürgisser $E$, et al: Correlation of platelet calcium with blood pressure: Effect of antihypertensive therapy. N Engl J Med 1984;310:1084.

15. Bruschi G, Bruschi ME, Caroppo $M$, et al: Cytoplasmic free $\mathrm{Ca}^{2+}$ is increased in the platelets of spontaneously hypertensive rats and essential hypertensive patients. Clin Sci 1985;68:179.

16. Zidek W, Vetter $\mathrm{H}$, Dorst $\mathrm{K}-\mathrm{G}$, et al: Intracellular $\mathrm{Na}^{+}$and $\mathrm{Ca}^{2+}$ activities in essential hypertension. Clin Sci 1982;63:41s.

17. Erne $P$, Resink TJ, Bolli $P$, et al: Free calcium response to adrenaline in platelets of normal and hypertensive (untreated and treated) subjects. J Hypertension 1985;2(suppl 3):159.

18. Devynck MA, Pernollet MG, Nunez AN, et al: Calcium binding alteration in plasma membrane from various tissues of spontaneously hypertensive rats. Clin Exp Hypertens 1982;4:797.

19. Kravtsov GM, Orlov SN, Pokudin NI, et al: Calcium transport in synaptosomes and subcellular membrane fractions of brain tissue in spontaneously hypertensive rats. Clin Sci 1983;65:127.

20. Kuchel O: The autonomic nervous system and blood pressure regulation in human hypertension, in Genest J,
Kuchel O, Hamet $P$, et al (eds): Hypertension Pathophysiology and Treatment. New York, McGraw-Hill, 1983, pp 140.

21. Resink TJ, Dimitrov D, Zschauer A, et al: Platelet calcium-linked abnormalities in essential hypertension. Ann NY Acad Sci 1986 (in press).

22. Watterson DM, Vincenzi FF (eds): Calmodulin and cell functions. Ann NY Acad Sci 1980;356:1.

23. Carafoli E, Zurini $\mathrm{M}$ : The $\mathrm{Ca}^{2+}$-pumping ATPase of plasma membranes: Purification, reconstitution and properties. Biochim Biophys Acta 1982;683:279.

24. Resink TJ, Tkachuk VA, Erne P, et al: Platelet membrane calmodulin-stimulated calcium-adenosine triphosphatase: Altered activity in essential hypertension. Hypertension $1985 ; 8: 159$.

25. Kwan CY, Grover AK, Sakai Y: Abnormal biochemistry of subcellular membranes isolated from nonvascular smooth muscles of spontaneously hypertensive rats. Blood Vessels 1982;19:273.

26. Wei J-W, Janis RA, Daniel EE: Calcium accumulation and enzymatic activities of subcellular fractions from aortas and ventricles of genetically hypertensive rats. Circ Res 1976;39:133.

27. Pernollet MG, Devynck MA, Meyer P: Abnormal calcium handling by isolated cardiac plasma membrane from spontaneously hypertensive rats. Clin Sci 1981;61:45s.

28. Aoki K, Yamashita K, Tomita N, et al: ATPase activity and $\mathrm{Ca}^{2+}$-binding activity of subcellular membranes of arterial smooth muscle in spontaneously hypertensive rats. Jpn Heart J 1974;15:180.

29. Katada T, Gilman AG, Watanabe Y, et al: Protein kinase $C$ phosphorylates the inhibitory guanine-nucleotidebinding regulatory component and apparently suppresses its function in hormonal inhibition of adenylate cyclase. Eur J Biochem 1985;151:431.

30. Marche P: Polyphosphoinositides and cell activation. Nouv Rev Fr Hematol 1985;27:223.

31. Michell RH: Inositol phospholipids and cell surface receptor function. Biochim Biophys Acta 1975;415:81.

32. Vergara J, Tsien RY, Delay M: Inositol 1,4,5-trisphosphate: A possible chemical link in excitation-contraction coupling in muscle. Proc Natl Acad Sci USA 1985;82:6352.

33. Allan D: Inositol lipids and membrane function in erythrocytes. Cell Calcium 1982;3:451.

34. Michell RH, Kirk CJ: Why is phosphatidylinositol degraded in response to stimulation of certain receptors? Trends Pharmacol Sci 1981;60:86.

35. Koutouzov S, Marche P, Girard A, et al: Altered turnover of polyphosphoinositides in the erythrocyte membrane of the SH rats. Hypertension 1983;5:409.

36. Marche P, Koutouzov S, Girard A, et al: Phosphoinositide turnover in erythrocyte membranes in human and experimental hypertension. J Hypertension 1985;3:25.

37. Dimitrov D, Resink TJ, Müller FB, et al: Altered platelet phosphatidylinositol metabolism in essential hypertension. J Hypertension 1986 (in press).

38. Boriskina AGM, Gulak PV, Postnov YV: Phosphoinosi- 
tide content in the erythrocyte membranes of rats with spontaneous and renal hypertension. Experientia 1978;34:744.

39. Kiselev G, Minenko A, Moritz V, et al: Polyphosphoinositide metabolism in erythrocytes of spontaneously hypertensive rats. Biochem Pharmacol 1981;30:833.

40. Namm DH: The role of cyclic nucleotides in the vasculature. Handbook Exp Pharmacol 1982;58:723.

41. Amer MS: Cyclic adenosine monophosphate and hypertension in rats. Science 1973;179:807.

42. Hamet $P$, Franks $A J$, Adnot $S$, et al: Cyclic nucleotides in hypertension. Adv Cycl Nucl Res 1980;12:11.

43. Resink TJ, Bürgisser E, Bühler FR: Enhanced platelet cyclic AMP response to prostaglandin $E_{1}$ in essential hypertension. Hypertension 1986;8:662.
44. Gilman AG: Guanine nucleotide-binding regulatory proteins and dual control of adenylate cyclase. J Clin Invest 1984;73:1.

45. Takai Y, Kikkawa U, Kaibuchi K, et al: Membrane phospholipid metabolism and signal transduction for protein phosphorylation. Adv Cycl Nucl Res 1984;18:119.

46. McNeil S, Lakey T, Tomlinson S: Calmodulin regulation of adenylate cyclase activity. Cell Calcium 1985;6:213.

47. Grigorian GY, Resink TJ, Stucki S, et al: Calmodulin regulation of adenylate cyclase activity in human platelet membranes. Cell Calcium 1986;7:261-273.

48. Rasmussen H, Goodman DBP: Relationships between calcium and cyclic nucleotides in cell activation. Physiol Rev 1977;57:421. 